\title{
BELAJAR MENGHARGAI KEARIFAN LOKAL DARI YESUS DALAM MATIUS 22:32
}

\author{
Noel Ghota Prima Bayu Surbakti \\ Sekolah Tinggi Teologi Sriwijaya \\ noelsurbakti@yahoo.co.id
}

\begin{abstract}
The churches in Indonesia live in a diversity of tribes, religions and cultures. We can find a variety of local wisdom that has been continuously sought to be preserved. But not all churches are willing to be open to local wisdom because of the presumption that local cultures are contrary to the Christian faith. Therefore, in this paper I want to invite the churches in Indonesia to open room to local wisdom. My effort is encouraging the churches to look at the figure of Jesus, who popularized the local wisdom that called the tradition of Theos Patros. Theos Patros tradition is the oldest tradition of the nation of Israel and has been known since the era of the ancestors but is no longer popular in the time of Jesus. But Jesus re-popularized the tradition because that tradition has a high noble value in line with the emphasis of the Gospel of Matthew.
\end{abstract}

Keywords: local wisdom, Jesus, Theos Patros, Matthew 22:32

\begin{abstract}
Abstrak. Gereja-gereja di Indonesia hidup dalam keberagaman suku, agama dan budaya. Kita dapat menemukan berbagai kearifan lokal yang belakangan ini terus diupayakan untuk dilestarikan. Namun tidak semua gereja bersedia terbuka terhadap kearifan lokal karena adanya anggapan bahwa kebudayaan lokal bertentangan dengan iman Kristen. Oleh karena itu tulisan ini hendak mengajak gereja di Indonesia untuk membuka ruang terhadap kearifan lokal. Upaya tersebut penulis wujudkan dengan mengajak gereja untuk melihat kepada sosok Yesus yang memopulerkan kearifan lokal yakni tradisi Theos Patros. Tradisi Theos Patros merupakan tradisi tertua bangsa Israel yang sudah dikenal sejak era leluhur tetapi sudah tidak populer lagi di zaman Yesus. Namun Yesus memopulerkan kembali tradisi tersebut sebab di dalamnya memiliki nilai luhur yang tinggi yang sejalan dengan penekanan Injil Matius.
\end{abstract}

Kata Kunci: kearifan lokal, Yesus, Theos Patros, Matius 22:32

Belakangan ini, wacana untuk menjaga kearifan lokal sangat kuat didengungkan. Presiden Jokowi pada saat berpidato dalam sidang tahun MPR 2019 mengatakan, "DPD juga telah menjadi ujung tombak dalam menjaga dan merevitalisasi nilai-nilai kearifan lokal” (Ryandi, 2019). Pernyataan tersebut sebagai respons atas usaha pemerintah, terkhusus Dewan Perwakilan Daerah (DPD), yang telah berjuang dalam menjaga nilai-nilai kearifan lokal belakangan ini. Tentu saja usaha tersebut tidak hanya diupayakan oleh DPD. Khofifah pada saat menjabat sebagai 
Menteri Sosial pernah menghimbau seluruh lapisan masyarakat terlibat di dalamnya, termasuk penguatan peran tokoh agama dalam mengusung kearifan lokal (Oktaviani, 2017). Dalam hal ini, dalam agama Kristen tidak hanya diwakili oleh tokoh-tokoh agama melainkan sebagai gereja. Dengan demikian, gereja sudah semestinya ikut serta dalam menjaga dan mengusung kearifan lokal.

Namun permasalahannya adalah adanya suatu pandangan yang menganggap kearifan lokal (warisan kebudayaan lokal) bertentangan dengan iman Kristen sehingga kerapkali kearifan lokal tersebut ditolak oleh gereja. Sikap penolakan terhadap kebudayaan lokal setidaknya telah terlihat melalui aktivitas pergerakan misi yang diprakarsai oleh misionaris Barat. Ariarajah yang menelusuri laporan-laporan pergerakan penginjilan mengatakan, "laporan-laporan akan ketidaktahuan, kekurangpekaan, dan penolakan terhadap kebudayaan lain, bahkan tak jarang mencapnya sebagai "primitif," "penyembah berhala," "kafir," atau "biadab" telah didokumentasikan dengan baik" (Ariarajah, 1997, p. 9). Sebagai konsekuensinya, penduduk lokal yang menjadi Kristen diharuskan agar tidak ambil bagian bahkan menolak kebudayaan lokal. Misalnya, ketika menjadi seorang Kristen harus melepaskan agama dan kebudayaan terdahulu yang ditandai dengan penolakan verbal verbal atau dengan tindakan-tindakan simbolis seperti pembakaran kitab-kitab atau bendabenda yang ada kaitannya dengan agama dan kebudayaan lama (Ariarajah, 1997). Purnawan Tenibemas berpendapat setidaknya ada dua 
alasan mengapa hal tersebut dapat terjadi, yakni: 1) Budaya orang Barat itu dipandang sebagai budaya "Kristen"; 2) Budaya lokal dipandang sebagai budaya kafir (Tenibemas, 2011).

Sikap penolakan terhadap kebudayaan tidak hanya terjadi pada era penginjilan. Sudah menjadi kesepakatan umum bahwa teologi kekristenan modern dipengaruhi oleh corak berteologi Barat. Fernando Segovia menyatakan "modern Christian Theology, I argued, was a theology that emanated from the center, grounded as it was in Western civilization" (Segovia, 2006). Gereja di Indonesia juga merupakan produk dari teologi Barat. Berdasarkan hal tersebut tersebut tidak bisa dipungkiri bahwa pada saat ini masih ada gereja di Indonesia yang mewarisi teologi barat khususnya terkait dengan sikap penolakan terhadap kebudayaan lokal. Perlu ditekankan bahwa tidak semua gereja bersikap demikian, namun jejak-jejaknya masih bisa ditemukan. Sebagai contoh misalnya pembakaran ulos Batak oleh seorang pendeta di Balige beberapa waktu yang lalu. Oleh karena itu, gereja yang dimaksud dalam tulisan ini yakni gereja yang masih menunjukkan sikap penolakan terhadap kebudayaan.

Tulisan ini hendak memperlihatkan sikap penolakan terhadap kebudayaan lokal tidak sepenuhnya benar sebab Yesus yang merupakan Kepala gereja ternyata menghargai kearifan lokal. Yesus pernah memopulerkan kembali salah satu kearifan lokal ${ }^{1}$ orang Israel yang sudah

${ }^{1}$ Penulis menyadari bahwa pada zaman Yesus belum dikenal istilah kearifan lokal. Istilah kearifan lokal yang dalam antropologi dikenal dengan istilah local genius pertama kali diperkenalkan oleh H.G. Quaritch Wales pada tahun 1961. la merumuskan 
ada sejak era leluhur Israel yakni tradisi Theos Patros. Dalam tulisan ini, penulis mengkhususkan penelitian terhadap tradisi Theos Patros yang dipopulerkan kembali dalam Injil Matius 22:32. Adapun alasan pemilihan Matius 22:32 dikarenakan sangat jarang ahli menyinggung kaitan teks tersebut dalam hubungan antara Yesus dengan kearifan lokal (bdk. Davies \& Allison, 1991; Hagner, 1995; Hill, 1990; Morris, 1992). Hal ini dapat dimaklumi karena konteks penafsir yang disebutkan tidak memiliki kepentingan dengan kearifan lokal sehingga dalam menafsir teks tersebut tidak mengaitkan hubungan Yesus dan kearifan lokal. Setidaknya hanya Pelita Surbakti dalam artikelnya yang berjudul "Menghidupkan Leluhur: Sebuah Penafsiran Terhadap Matius 22:32" yang mengaitkan teks tersebut dengan tradisi Theos Patros sebagai kearifan lokal bangsa Israel. Namun, jika Surbakti memperlihatkan gagasan yang ada dalam Matius 22:32, tulisan ini lebih kepada mengajak pembaca untuk melihat sosok Yesus yang menghargai kearifan lokal. Melalui penelitian ini diharapkan gereja dapat menghargai kearifan lokal sebagaimana Yesus yang merupakan Kepala gereja juga menghargai kearifan lokal.

\section{METODE}

Dalam tulisan ini, penulis akan membaca Matius 22:32 dalam kacamata hermeneutika poskolonial. Dalam studi Alkitab, Sugirtharajah adalah salah satu tokoh yang menaruh perhatian pada hermeneutika

local genius dengan "the sum of the cultural characteristic which the vast majority of a people have in common as a result of their experiences in early life" s Berdasarkan perumusan tersebut, tradisi Theos Patros dalam bangsa Israel ini dapat pula dikatakan sebagai kearifan lokal. 
poskolonial. la mengusulkan bahwa teks Alkitab dan penafsiran harus dicermati dengan baik untuk merumuskan kembali identitas kultur lokal yang selama ini terabaikan (Sugirtharajah, 2012). Oleh karena itu penulis akan membaca Matius 22:32 melalui kacamata hermeneutika poskolonial untuk melihat gagasan penghargaan Yesus terhadap kearifan lokal.

\section{HASIL}

Tradisi Theos Patros yang tampak dalam frasa "Allah Abraham, Allah Ishak dan Allah Yakub" merupakan tradisi keagamaan tertua bagi bangsa Israel yang sudah dikenal sejak era leluhur. Namun dalam perkembangan keagamaan Israel, khususnya setelah mereka keluar dari Mesir menuju tanah perjanjian, tradisi Theos Patros menjadi tidak populer karena digantikan oleh Yahwisme yang berpusat pada Allah yang bernama Yahweh. Semenjak itu semua berpusat kepada Allah yang bernama Yahweh. Setelah pembuangan bahkan muncul sikap eksklusivisme dan konservatisme dalam keagamaan Israel yang menyebabkan agama Israel menjadi statis. Hal ini menyebabkan tradisi keagamaan diluar Yahwisme ditolak. Tetapi di zaman-Nya, Yesus dalam Injil Matius memopulerkan kembali tradisi Theos Patros yang populer pada zaman era leluhur Israel atau sebelum munculnya tradisi Yahwisme. Hal tersebut bukan tanpa alasan. Dalam tradisi Theos Patros ternyata menekankan pentingnya peranan leluhur yakni Abraham, Ishak dan Yakub yang dipandang sebagai patron atau teladan bagi umat Israel. Teladan memang menjadi kebutuhan yang mendesak bagi pembaca pertama 
Matius sebab para pemimpin agama Yahudi telah gagal menjadi teladan. Mereka gagal sebab mereka mengajar tetapi tidak melakukan apa yang mereka ajarkan. Oleh karena itu Yesus memopulerkan kembali tradisi Theos Patros untuk mengangkat sosok Abaham, Ishak dan Yakub sebagai patron melakukan firman Tuhan bagi pembaca Injil Matius. Dalam hal ini dapat dilihat bahwa Yesus menghargai kearifan lokal meskipun pada saat itu sudah tidak populer bahkan ditolak akibat eksklusivitas keagamaan Yahwisme. Tetapi para ahli pada umumnya jarang bahkan hampir tidak pernah mengaitkan ayat tersebut dengan upaya Yesus untuk menghargai kearifan lokal. Oleh karena itu penulis membaca teks tersebut dalam kacamata hermeneutika poskolonial di mana Yesus ternyata menghargai kearifan lokal. Dalam Matius 22:32 Yesus memopulerkan kembali salah satu tradisi tertua dalam bangsa Israel yakni tradisi Theos Patros. Di dalam tradisi tersebut terkandung nilai-nilai luhur yakni keteladan Abraham, Ishak dan Yakub yang dapat dijadikan sebagai patron dalam melakukan Firman Tuhan. Dalam hal ini Yesus menggunakan kearifan lokal dalam pengajarannya. Demikilan pula gereja dapat belajar menghargai kearifan lokal dari sosok Yesus.

\section{PEMBAHASAN}

\section{Tradisi Theos Patros}

Dalam Matius 22:32, Yesus menyebutkan frasa "Allah Abraham, Allah Ishak dan Allah Yakub." Jika kita telusuri, frasa tersebut merupakan salah satu tradisi penyebutan Allah pada era leluhur Israel. Dalam sebuah 
tulisan yang berjudul "The God of the Father", Albrecht Alt menguraikan tradisi keagamaan pada era leluhur $|s r a e|^{2}$ terdiri dari dua bagian besar (Alt, 1989). Tradisi pertama disebut sebagai "Agama El”. Tradisi Agama EI tersebut telah dipraktikkan sebelum mereka menempati Palestina. Dari lima nama yang muncul dalam $\mathrm{PL}$, tiga di antaranya dikaitkan dengan tempat-tempat suci tertentu yakni: El Bet'el (Betel), El 'Olam (Bersyeba), dan El Ro'i (di Selatan). Dua yang lainnya tidak dikaitkan dengan tempat tertentu yakni El 'Elyon dan El Saddai. Tradisi ini merupakan praktik religiositas kuno di Palestina dan Siria. Namun, Alt menegaskan bahwa tradisi tersebut tidak dapat dimasukkan ke dalam natur asli tradisi agama suku-suku Israel atau dengan kata lain tradisi El bukanlah ciri khas asli leluhur Israel (Alt, 1989). Alt berpendapat bahwa tradisi kedua yang ia sebut dengan God of the Fathers merupakan religiositas yang asli dan tertua dari suku-suku Israel (Alt, 1989). Tradisi ini merupakan sebuah identifikasi Allah yang dikaitkan dengan nama seseorang. Dalam PL indikasi tradisi tersebut muncul melalui frasa-frasa semacam: "Allah ayahmu," "Allah ayahku," "Allah Abraham," "Allah Ishak," "Allah Yakub," dan sebagainya. Tradisi tersebut dikenal sebagai tradisi "God of the Fathers" - "teos patros" - yakni Allah yang disembah oleh para leluhur Israel (Alt, 1989).

Penelitian Alt tersebut diteruskan pula oleh muridnya yang bernama Vriezen. la meneliti agama pra-Israel dengan mengupayakan bahan

${ }^{2}$ Era yang dimaksud adalah era pra-Israel yakni sebelum suku-suku Israel bersatu dan menyembah kepada Yahweh. 
Alkitab dan non-Alkitab. Bahan Alkitab bersumber dari sumber Yahwis, Elohis dan Priest (Imamat) sedangkan bahan-bahan non-alktabiah misalnya diambil yang berkenaan dengan periode para patriarkh (tahun 1700-1220 sM) seperti naskah Mari dan Nuzu. Sumber non-Alkitabiah ini menunjukkan bahwa adanya nama-nama yang secara etimologis terkait dengan nama-nama yang terdapat dalam riwayat-riwayat Alkitab mengenai para patriarkh yang sudah berlaku sejak abad ke-18 sM. Melalui penelitian tersebut ditemukan unsur terkuno dalam agama para patriarkh yakni kepercayaan kepada "Theos Patroos" (Allah nenek moyang). Konsep ini dapat dilihat dalam frasa "Allah Abraham," "Pakhad Ishak," dan "Abir Yakub." Dengan cara tertentu leluhur Israel telah memperoleh hubungan dengan Allah sehingga Allah dikaitkan dengan nama leluhur Israel yang mana unsur pokok di sini yakni hubungan pribadi Allah dengan orang yang telah mengalami penyataan-Nya.

Namun perlu disadari, tradisi Theos Patros juga mendapat pengaruh dari suku-suku di sekitar leluhur Israel. Vriezen demikian pula Lemmelijn \& Merriga berpendapat bahwa tradisi Theos Patros ini memiliki banyak persamaan dengan agama-agama di sekitar leluhur Israel (Lemmelijn \& Merrigan, 2006; Vriezen, 2015). Karena itulah tradisi tersebut dianggap mendapat pengaruh dari bangsa lain. Alt menduga pengaruh tersebut diperoleh ketika leluhur Israel hidup nomaden di padang gurun Arab, peradaban Palestina dan Siria. Tetapi tetap saja figur 
Allah diidentikkan dengan leluhur Israel sehingga menjadi karakteristik dan agama khas dari leluhur Israel (Alt, 1989).

Berdasarkan penjelasan di atas dapat dilihat bahwa ada dua tradisi dalam periode leluhur Israel yakni tradisi El dan Theos Patros di mana yang terakhir disebut ini merupakan tradisi tertua dalam Israel. Tetapi dalam periode berikutnya, tepatnya pada periode antara zaman para leluhur Israel dan zaman para Hakim, bangsa Israel masuk dalam suatu bentuk keagamaan yang baru di mana segala sesuatu berpusat pada Allah yang bernama Yahweh (Vriezen, 2015). Yahwisme tersebut berkembang pesat namun pada awalnya tetap menyesuaikan diri dengan bentuk agama yang sudah berkembang sebelumnya yakni tradisi El dan Theos Patros (Vriezen, 2015). Tetapi dalam periode yang panjang meliputi masa kerajaan, pecahnya kerajaan menjadi Israel Utara dan Selatan, periode pembuangan ke Babel hingga pemulangan kembali ke Yerusalem, terjadi perubahan yang signifikan dalam agama tersebut. Agama Yahweh yang awalnya dinamis berubah menjadi statis dan kaku karena eksklusivisme dan konservatisme. Hal ini sesungguhnya sebagai konsekuensi dari peristiwa pembuangan ke Babel. Eksklusivisme terjadi ketika sisa-sisa bangsa Israel pulang ke tanah airnya. Hal tersebut terjadi bukan hanya untuk mempertahankan identitas keagamaan Israel, namun juga untuk mempertahankan eksistensinya sebagai bangsa. Semenjak itu, ekspresi-ekspresi lain diluar tradisi Yahwisme tidak mungkin lagi dapat muncul dalam agama Israel termasuk tradisi Theos Patros (Vriezen, 
2015). Penyebutan nama Allah hanya tertuju kepada Yahweh. Hal ini sangat jelas terlihat di mana teks-teks yang muncul setelah pembuangan (bahkan sebelumnya) sangat jarang bahkan tidak pernah lagi menyandingkan Allah dengan nama leluhur. Dalam Perjanjian Baru (PB), hanya 5 kali penyandingan Allah dengan nama leluhur (bdk. Matius 22:32; Markus 12:26; Lukas 20:37; Kisah Para Rasul 3:13; 7:32).

Dengan demikian menarik untuk dikaji ketika Yesus dalam Matius 22:32 kembali menyebutkan frasa "Allah Abraham, Allah Ishak dan Allah Yakub." Frasa tersebut merupakan karakteristik dari tradisi Theos Patros yang sesungguhnya sudah tidak populer bahkan ditolak pada saat itu. Namun Yesus justru memopulerkannya kembali. Ternyata tradisi tersebut memiliki signifikansi khususnya bagi pembaca pertama Injil Matius pada saat itu.

\section{Signifikansi Tradisi Theos Patros dalam Matius 22:32}

Berdasarkan pengamatan penulis, sangat sedikit ahli yang membahas secara mendalam makna tradisi Theos Patros dalam Matius 22:32. Meskipun demikian penelitian-penelitian tersebut akan sangat menolong untuk menemukan signifikansi tradisi Theos Patros tersebut dalam Matius 22:32. Arthur Carr dalam sebuah buku tafsiran klasik mengaitkan tradisi Theos Patros dalam Matius 22:32 dengan realitas relasi antara Allah dengan bapa leluhur Israel semasa hidupnya (Carr, 1887). Hampir senada, Leon Morris juga mengatakan tradisi Theos Patros 
sebenarnya tidak hanya berbicara tentang Allah, namun juga berbicara tentang para leluhur yang namanya disebutkan (Morris, 1992).

Jika ditelusuri kembali ke era leluhur Israel, tradisi Theos Patros memang tidak hanya berbicara tentang Allah tetapi juga para leluhur yang namanya disandingkan dengan nama Allah tersebut. Fungsi penyebutan nama Allah yang disandingkan dengan nama manusia tampaknya menegaskan ikatan antara Allah dengan orang yang menyebutkan frasa tersebut atau dengan orang yang kepadanya Allah memperkenalkan diri dengan masing-masing frasa tersebut (Alt, 1989). Vriezen mengatakan, "unsur-unsur pokok dalam Allah leluhur ialah bahwa Dia berkepribadian dan mempunyai hubungan pribadi dengan orang yang telah mengalami penyataan-Nya” (Vriezen, 2000, p. 120). Rowley juga menambahkan, “... hubungan antara leluhur dengan Allah bercirikan suatu keintiman" (Rowley \& Cairns, 2012). Dari pernyataan para ahli tersebut dapat disimpulkan bahwa dalam tradisi Theos Patros memang memuat gagasan keintiman antara Allah dengan leluhur (manusia).

Tetapi tentu saja ada alasan atau kualifikasi tertentu mengapa Allah menjalin hubungan intim dengan Abraham, Ishak dan Yakub. Di dalam diri leluhur Israel tersebut ada gambaran tabiat yang luhur dan tinggi (Rowley \& Cairns, 2012). Menurut John Skinner, sebagaimana dikutip oleh Rowley, "riwayat hidup Abraham memperlihatkan suatu kesatuan rohani bertemakan iman yang makin kuat. Sikap rohani itu berbuahkan suatu tabiat yang sungguh luhur dan agung..." (Rowley, 2012, p. 26). la 
menambahkan para leluhur memang mengandung "noda" (band. Kej. 12:10-20; 20:1-18), namun dengan dikecualikannya noda itu, gambaran tentang tabiat Abraham memang luhur dan tinggi (Rowley \& Cairns, 2012). Noda yang dimaksud berkaitan dengan sikap Abraham yang menyatakan bahwa Sara adalah saudaranya. Dalam peristiwa tersebut seringkali Abraham dipandang sedang menipu karena menyebut Sara yang merupakan istrinya adalah saudaranya. Namun menurut Barnabas Ludji dalam hal ini sebenarnya Abraham tidak bermaksud menipu, sebab dalam kebudayaan suku Abraham memang menyapa istri sebagai saudara perempuan (Ludji, 2009). Karena itu memang benarlah bahwa Abraham, Isak dan Yakub memiliki kualifikasi tertentu yakni riwayat hidup mereka yang luhur dan agung. Allah menjalin relasi yang intim dengan mereka karena tabiat yang luhur.

Telah terlihat bahwa dalam tradisi Theos Patros tersebut ternyata berbicara juga mengenai peranan leluhur Israel yakni Abraham, Ishak dan Yakub yang memiliki tabiat luhur dan agung. Namun apakah signifikansi bagi pembaca Matius? Dalam artikelnya yang berjudul "Menghidupkan Leluhur: Sebuah Penafsiran terhadap Matius 22:32", Pelita Surbakti menekankan bahwa aspek kekinian dari hidup para bapa leluhur Israel seharusnya disinggung; bahwa sesungguhnya mereka tetap hidup di tengah-tengah keturunan mereka walau tubuhnya telah menjadi debu (Surbakti, 2019). Para leluhur ini sesungguhnya terus menuntun kehidupan keturunannya walau mereka telah mati. Bagi generasi yang 
masih hidup, leluhur tersebut terus menjadi patron bagi upaya untuk mewujudkan religiositas yang berkenan kepada Allah. Adapun patron yang dimaksud berkaitan dengan melakukan firman Allah.

Hal tersebut memang sesuai dengan agenda penulis Matius dalam Injilnya. ${ }^{3}$ Pembaca pertama Injil Matius membutuhkan sebuah patron untuk melakukan firman Allah karena para pemimpin agama Yahudi gagal menjadi patron. Kegagalan mereka terletak pada tataran praktik, di mana mereka mengajar tetapi tidak melakukan apa yang mereka ajarkan (Surbakti, 2017). Kesimpulan ini didukung pernyataan Yesus dalam Matius 23:3, "Sebab itu turutilah dan lakukanlah segala sesuatu yang mereka ajarkan kepadamu, tetapi janganlah kamu turuti perbuatan-perbuatan mereka, karena mereka mengajarkannya tetapi tidak melakukannya" (Mat. 23:3). Dengan demikian Yesus mengangkat tokoh Abraham, Ishak dan Yakub, sebagai model keteladanan sebab mereka melakukan kehendak Bapa, tidak seperti para pemimpin Yahudi yang mengajar tetapi tidak melakukan.

Dengan demikian terlihat sebuah alasan mengapa Yesus memopulerkan kembali tradisi Theos Patros. Sebab dalam tradisi tersebut terdapat sebuah gagasan yang sangat penting dan mendesak bagi pembaca Injil Matius yakni sosok teladan yang terwujud melalui tokoh

\footnotetext{
${ }^{3}$ Agenda yang dimaksud berkaitan dengan tema utama dan hakikat Injil Matius. Argumentasi yang cukup komprehensif dari kesimpulan yang menyatakan "Allah Bersama Kita" sebagai tema utama Injil ini serta "Retorika Pertarungan Kepemimpinan" sebagai hakikat retorika Injil Matius dapat dibaca dalam Pelita H. Surbakti, Yang Terutama dalam Amanat Agung: Sebuah Pencarian Makna Kata Tērein dalam Matius 28:20a (Jakarta: BPK Gunung Mulia, 2017), 29-74.
} 
Abraham, Ishak dan Yakub. Melakukan kehendak Bapa merupakan penekanan utama dalam Injil Matius (Surbakti, 2017). Leluhur Israel merupakan model keteladanan dalam melakukan kehendak Bapa bagi pembaca Injil Matius.

\section{KESIMPULAN}

Berdasarkan penjelasan di atas kita dapat melihat bahwa Yesus sang Kepala gereja menghargai tradisi leluhur Israel yang sudah tidak populer di zaman Yesus yakni tradisi Theos Patros. Upaya Yesus menghargai tradisi tersebut tentu bukan tanpa alasan. Dalam tradisi Theos Patros ternyata memuat gagasan teladan dari para leluhur yakni Abraham, Ishak dan Yakub yang memiliki tabiat luhur dan mulia. Sosok tersebut sangat dibutuhkan bagi pembaca Injil Matius sebagai patron untuk melakukan firman Tuhan. Hal tersebut dikarenakan para pemimpin agama Yahudi gagal menjadi teladan di mana mereka mengajar tetapi tidak melakukan apa yang mereka ajarkan. Dengan demikian Yesus mengangkat sosok Abraham, Ishak dan Yakub melalui tradisi Theos Patros sebagai patron dalam melakukan firman Tuhan.

Melalui tulisan ini diharapkan dapat mengajak gereja untuk membuka ruang bagi kearifan lokal. Kita dapat belajar dari Yesus sang Kepala gereja yang juga menghargai kearifan lokal pada zaman-Nya sebab ada gagasan luhur yang terkandung di dalamnya. Gereja di Indonesia hidup dalam keberagaman suku, agama dan budaya. Di dalamnya terdapat begitu banyak kearifan lokal yang memiliki nilai luhur 
yang tinggi yang dapat diterapkan atau diadopsi di dalam gereja (misalnya kearifan lokal runggu dalam masyarakat Karo yang mementingkan musyawarah dan kesepakatan bersama). Tetapi bukan berarti kita sangat mengagung-agungkan kebudayaan lokal lalu kemudian menerima semuanya. Gereja diharapkan terus menerus melakukan pergumulan teologis terhadap kearifan lokal secara kritis. Karena di dalam kebudayaan lokal juga mungkin memuat unsur-unsur negatif seperti patriakhal, penindasan dsb. Bersikap kritis berarti mengkritisi unsur-unsur negatif dalam kebudayaan sebagaimana telah disebutkan sebelumnya. Tetapi faktanya selama ini ada kesan bahwa segala sesuatu yang berhubungan dengan budaya harus ditolak tanpa adanya kajian atau penelitian terlebih dahulu. Misalnya seperti pembakaran ulos oleh gereja seperti yang penulis sebutkan sebelumnya. Apakah sebelum melakukan tindakan pembakaran tersebut sudah ada upaya untuk mengkaji nilai-nilai atau gagasan dalam ulos tersebut? Atau hanya dengan anggapan bahwa itu merupakan bagian dari kebudayaan maka harus ditolak oleh gereja bahkan sebelum mengkaji gagasan di dalamnya.

Dengan demikian melalui tulisan ini diharapkan gereja mau membuka ruang terhadap kearifan lokal dengan mengkaji kembali nilainilai yang terkandung di dalamnya. Nilai-nilai yang memiliki gagasan luhur dan tidak bertentangan dengan nilai-nilai kekristenan tentu dapat dihargai. Di dalam kearifan lokal dapat ditemukan nilai-nilai luhur sebagaimana yang ditemukan pula dalam kekristenan. Gereja di Indonesia yang hidup 
dalam keberagaman suku, agama dan kebudayaan dapat belajar dari Yesus yang menghargai kearifan lokal.

\section{DAFTAR PUSTAKA}

Alt, A. (1989). The God of the Father. In D. E. Orton (Ed.), Essay on Old Testament: History and Religion. Sheffield: Sheffield Academic Press.

Ariarajah, W. S. (1997). Injil dan Kebudayaan (L. S. K. \& Y. Kristono, Ed.). Jakarta: BPK Gunung Mulia.

Carr, A. (1887). Cambridge Greek Testament: The Gospel According to St. Matthew. Cambridge: Cambridge University Press.

Davies, W. D., \& Allison, D. . (1991). Matthew 19-28. London: T\&T Clarck.

Hagner, D. (1995). World Biblical Commentary: Matthew 14-28. Nashville: Thomas Nelson Publisher.

Hill, D. (1990). The New Century Bible Commentary: The Gospel of Matthew. Grand Rapids: William B. Eerdmans Publishing Company.

Lemmelijn, B., \& Merrigan, T. (2006). From the God of the Fathers to God the FAther. Louvain Studies.

Ludji, B. (2009). Pemahaman Dasar Perjanjian Lama. Bandung: BMI.

Morris, L. (1992). The Gospel According to Matthew. Grand Rapids: Eerdmans.

Oktaviani, Z. (2017). Mensos Dorong Pengembangan Kearifan Lokal. Retrieved June 18, 2019, from Republika.co.id website: https://www.republika.co.id/berita/nasional/politik/17/11/30/p07t5t319mensos-dorong-pengembangan-kearifan-lokal

Rowley, H. H., \& Cairns, I. (2012). Ibadat Israel kuno. Jakarta: BPK Gunung Mulia.

Ryandi, D. (2019). Jokowi: DPD Jadi Ujung Tombak Nilai-Nilai Kearifan Lokal. Retrieved September 18, 2019, from JawaPos.com website: https://www.jawapos.com/nasional/politik/16/08/2019/jokowi-dpd-jadiujung-tombak-nilai-nilai-kearifan-lokal/ 
Segovia, F. (2006). Biblical Criticism and Postcolonial Studies. In R. S. Sugirtharajah (Ed.), The Postcolonial Biblical Reader. Oxford: Blackwell Publishing.

Sugirtharajah, R. S. (2012). Exploring Postcolonial Biblical Criticism: History, Method, Practice. https://doi.org/10.1002/9781444396652

Surbakti, P. (2017). Yang Terutama dalam Amanat Agung. Jakarta: BPK Gunung Mulia.

Surbakti, P. H. (2019). Menghidupkan Leluhur: Sebuah Penafsiran Terhadap Matius 22:32. GEMA TEOLOGIKA: Jurnal Teologi Kontekstual Dan Filsafat Keilahian, 4(1), 1. https://doi.org/10.21460/gema.2019.41.414

Tenibemas, P. (2011). Misi yang Membumi. Bandung: STT Tiranus.

Vriezen, T. C. (2015). Agama Israel Kuno (I. J. Cairns, Ed.). Jakarta: BPK Gunung Mulia. 